\title{
Flow Structure and Channel Stability at the Site of a Deep Scour Hole, Mackenzie Delta, Canada \\ SPYROS BELTAOS,,${ }^{1,2}$ BOMMANNA G. KRISHNAPPAN, ${ }^{1}$ ROBERT ROWSELL, ${ }^{1}$ TOM CARTER, ${ }^{3}$ ROGER PILLING ${ }^{4}$ and PAUL EMILE BERGERON 5
}

(Received 8 June 2011; accepted in revised form 13 September 2011)

\begin{abstract}
Unusually deep scour holes in distributary channels of the Mackenzie Delta are of concern for oil and gas resource development, particularly with respect to buried pipeline crossings. Surveys of one such hole, carried out in 1985 and 1992, indicated vertical stability and slight lateral movement. The present study examines how the hole may have changed by the mid-2000s and documents the complex local velocity field and related bed material properties. Small discrepancies between isobaths of different years suggest a dynamic stability that involves short-term fluctuations in erosion and deposition. This suggestion was corroborated by detailed measurements of the highly three-dimensional velocity field, which revealed major eddy structures and flow reversals that help maintain sizeable velocity magnitudes despite low mean velocities. The composition of the bed material suggests cohesive behaviour, but the literature indicates a range of critical shear stresses that spans two orders of magnitude. The more probable lower end of this range is consistent with the observed dynamic stability of the scour hole.
\end{abstract}

Key words: bathymetry, bed material, deposition, erosion, flow reversal, scour hole, shear stress, stability, turbulence, velocity field

RÉSUMÉ. Des fosses d'affouillement exceptionnellement profondes se trouvant dans les effluents du delta du Mackenzie risquent de poser des problèmes en matière de mise en valeur des ressources pétrolières et gazières, surtout en ce qui a trait aux pipelines enfouis. Selon les levés d'une de ces fosses effectués en 1985 et en 1992, cette fosse serait verticalement stable et aurait un léger mouvement latéral. La présente étude se penche sur la façon dont la fosse pourrait avoir changé une fois rendu vers le milieu des années 2000 et documente le champ de vitesse local complexe de même que les propriétés des matériaux de fond connexes. De petits écarts entre les isobathes de différentes années laissent entrevoir une stabilité dynamique assortie de fluctuations à court terme sur le plan de l'érosion et de la déposition. Cette suggestion a été corroborée à l'aide de mesures détaillées du champ de vitesse hautement tridimensionnel, qui a révélé d'importantes structures à grands tourbillons et des écoulements de retour qui favorisent le maintien d'intensités de vitesse appréciables malgré des vélocités moyennes faibles. Bien que la composition des matériaux de fond suggère un comportement cohésif, la documentation indique une gamme de contraintes de cisaillement critique qui s'étend sur deux ordres de grandeur. Le bas de cette gamme plus probable est conforme à la stabilité dynamique observée à l'égard de la fosse d'affouillement.

Mots clés : bathymétrie, matériaux de fond, dépôt, érosion, écoulement de retour, fosse d'affouillement, contrainte de cisaillement, stabilité, turbulence, champ de vitesse

Traduit pour la revue Arctic par Nicole Giguère.

\section{INTRODUCTION}

Environmental and industrial concerns associated with oil and gas resource development in the Mackenzie Delta, Northwest Territories, Canada, have motivated numerous studies on the morphology and fluvial processes of the distributary channels of the delta. In the course of such investigations, which were partly motivated by the need to identify potential pipeline crossings, many deep holes were discovered in the beds of various delta channels (T. Blench and Associates Ltd., 1974; Lapointe, 1984, 1985, 1986a; Beltaos et al., 2011). The morphology, depth, and mobility of scour holes are highly relevant to the security of buried pipelines that may be crossing under delta channels. Scour-induced exposure could lead to pipeline rupture, with serious economic and ecological consequences.

\footnotetext{
${ }^{1}$ Water Science and Technology Directorate, Environment Canada, 867 Lakeshore Road, Burlington, Ontario L7R 4A6, Canada

${ }^{2}$ Corresponding author: Spyros.Beltaos@ec.gc.ca

${ }^{3}$ Water Science and Technology Directorate, Environment Canada, 11 Innovation Boulevard, Saskatoon, Saskatchewan S7N 3H5, Canada

${ }^{4}$ Water Survey of Canada, Environment Canada, Fort Simpson, Northwest Territories X0E 0N0, Canada

${ }^{5}$ Hydrometric Operations, Environment Canada, 29 de Varennes Street, Gatineau, Quebec J8T 8G7, Canada

(C) Her Majesty the Queen in Right of Canada. Administered by the Arctic Institute of North America.
} 


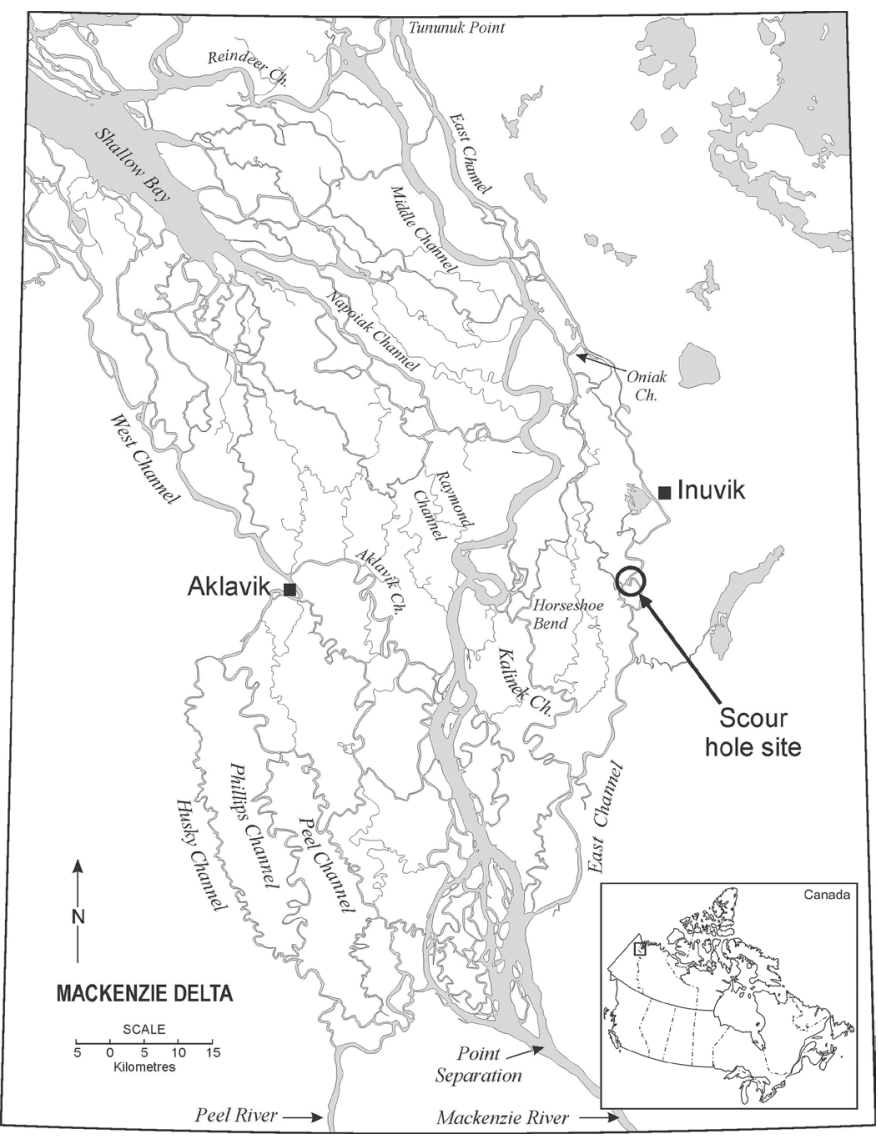

FIG. 1. Mackenzie Delta and location of the study site. Only relatively large channels are shown. Map boundaries: $67.5^{\circ}$ to $69^{\circ} \mathrm{N} ; 133^{\circ}$ to $136^{\circ} \mathrm{W}$.

Most of the deep holes occur at morphologically unexpected locations and are much deeper than can be expected from findings on other rivers (Hollingshead and Rundquist, 1977; Lapointe, 1986a; Beltaos et al., 2011). One such deep hole, located in the East Channel of the Mackenzie Delta (Figs. 1 and 2), has been chosen for more detailed study by Environment Canada, owing to its size, persistence, and accessibility. Fassnacht and Conly (2000) found that the hole bathymetry, as measured in 1992, had changed little since the first detailed survey in 1985 (Lapointe, 1986a). They also cited evidence from navigation charts suggesting that the hole existed as early as 1953. In the remainder of the paper, the term scour hole $(\mathrm{SH})$ will refer to this particular hole unless otherwise indicated. The channel plan in Figure 2 illustrates a feature that is often encountered near a scour hole. This is a recess in the channel boundary, known as a "scour bay" (Lapointe, 1985).

Conventional wisdom suggests that the mean-velocity reduction associated with a deep channel section would promote sediment deposition and eventual infilling of the hole. However, major perturbations in the channel boundaries can induce flow separation and greatly alter the velocity field. In such instances, mean velocity is not a meaningful index of velocity magnitude within a channel cross section, but there is no information on how the scour holes modify local flow characteristics. To elucidate the detailed

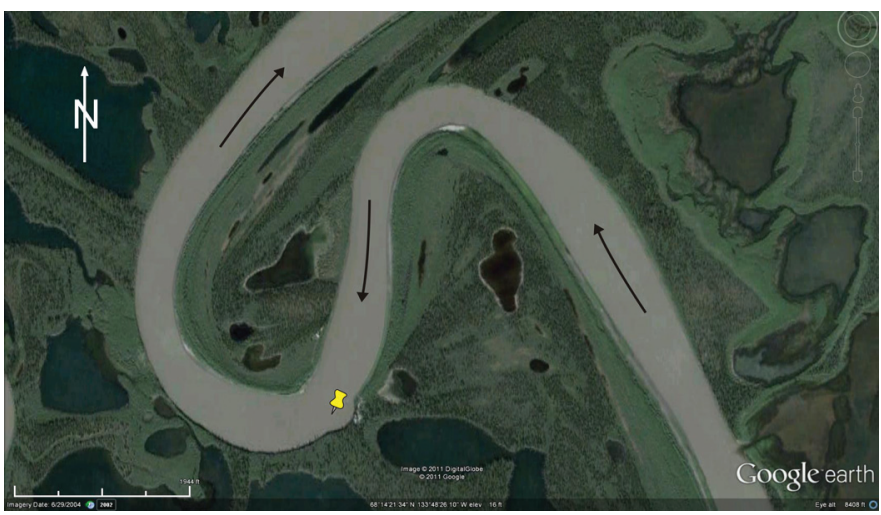

FIG. 2. Plan view of East Channel in the vicinity of the scour hole. The pin approximately indicates the deepest location in the scour hole. The scale bar indicates a length of $\sim 600 \mathrm{~m}$. Image source: Google Earth. Imagery date: 29 June 2004. Copyright 2011 Google; image copyright 2011 DigitalGlobe.

flow structure in the $\mathrm{SH}$, measurements of the velocity field were carried out in June 2005 and September 2007 using an Acoustic Doppler Current Profiler (ADCP). The times of the measurements represent conditions of relatively high (June) and low (September) flow. In addition to unique three-dimensional velocity data, the ADCP surveys provided detailed bathymetric information, which can be used to assess the stability of the $\mathrm{SH}$ since 1992.

The main objectives of this paper are to describe and quantify the velocity field in the scour hole area, as well as in upstream and downstream reaches; compare past and recent $\mathrm{SH}$ bathymetries; and examine whether the observed structure of the flow can explain hole stability.

\section{BACKGROUND INFORMATION}

Hill et al. (2001), Black and Fehr (2002), and Burn and Kokelj (2009) summarize a wealth of information pertaining to the Mackenzie Delta, the world's second largest Arctic delta, and second only to the Mississippi River delta in North America. The delta is almost flat, with water levels at its entrance (Point Separation) usually less than $10 \mathrm{~m}$ above sea level, and it is filled with lakes and channels (Fig. 1). Over 49000 lakes cover the deltaic plain (Emmerton et al., 2007), which is crisscrossed by numerous channels of various sizes that convey water from the major river branches to the lakes and vice versa. Most of the flow supplying the various delta channels comes from the Mackenzie River. The annual flood typically occurs in late May or early June and is generated by high spring flows and backwater caused by occasional ice jams. Flooding helps maintain the delta lakes and floodplain ecosystems by supplying river water, sediment, and nutrients.

Lapointe $(1984,1985,1986 a$, b) reported that bank erosion is ubiquitous along channel bends and even in straight reaches, but is by far most pronounced along the Middle Channel (Fig. 1), where migration rates of $10 \mathrm{~m} / \mathrm{yr}$ or more are common. In smaller channels, migration rates may be up to several $\mathrm{m} / \mathrm{yr}$, but typically range from 0.1 to $2 \mathrm{~m} / \mathrm{yr}$. 
Lapointe also presented data on the bed material of delta channels, starting with gravels and medium-to-coarse sands that were sampled on the Mackenzie River just downstream of Point Separation. Limited sampling downstream indicated that medium and fine sands dominate on the bed of the Middle Channel, with extensive dune fields. In contrast, sampling along smaller delta channels revealed predominance of silt-slurry bed materials with variable but usually minor fine-sand fractions. In Shallow Bay and nearby channels (outer delta; not shown in Fig. 1), the bed materials consist predominantly of fine sands and silts with minor amounts of clay and organic material (Hollingshead and Rundquist, 1977).

Fassnacht and Conly (2000) presented the results of bathymetric and bed material surveys of the East Channel SH that were carried out in July 1992. Comparison with Lapointe's 1985 bathymetry indicated vertical stability but possible lateral migration via erosion and deposition, at an average rate of $0.8 \mathrm{~m} / \mathrm{yr}$, during the intervening seven years. Detailed information on bed material composition in the SH area, as well as in the entry and exit reaches upstream and downstream, was also collected (Fassnacht, 1993) and discussed by Fassnacht and Conly (2000). Sand, silt, and clay fractions varied widely from point to point, in both the longitudinal and the transverse directions. Most samples contained enough clay to render them cohesive (Fassnacht, 1993).

A 2004 bathymetric survey of an extensive reach of East Channel revealed many additional scour holes and led to development of an inventory of all known holes (Beltaos et al., 2011). The scour depth for some of the holes was within the range normally expected from local river morphology (e.g., bends, confluences, constrictions), but many holes were "abnormally" deep and associated with nearby scour bays. Beltaos et al. (2011) critically examined various hypotheses that had been previously advanced to explain the origin of the scour holes. They showed that river ice processes, such as ice jamming and related scour, could not explain the observed depth magnitudes. Lake capture by migrating channels and the ensuing development of hydraulic conditions causing very deep scour were deemed a likely mechanism that could also explain the presence of scour bays. Permafrost would be a key factor in this process, rendering the Mackenzie Delta scour holes uniquely northern morphological features.

\section{DATA COLLECTION PROGRAM}

The objectives of the field data collection program were to measure the local velocity field and explore possible flow reversals and eddying motions, survey local bathymetry for comparisons with previous data, and obtain bed material cores for particle size and caesium content analyses at different depths below the bed surface.

\section{Acoustic Doppler Current Profiler Applications}

The first two objectives of the field program were addressed via ADCP technology (broadband $600 \mathrm{kHz}$; beam angle: $20^{\circ}$ ). The transducer was mounted on a boat that slowly traversed the channel at several transects. Using sophisticated trigonometric and statistical techniques, the profiler software converts raw velocity and GPS data to velocity components in an earth-based reference frame, such as East, North, Up (Gordon, 1996). The horizontal components can be further transformed into streamwise and transverse velocities via simple trigonometric equations. Velocities are averaged over small elements, called cells or bins, of user-specified vertical dimension $(0.5 \mathrm{~m}$ in the present applications).

ADCP output can be processed, manipulated, and visualized using the "WinRiver" program (RD Instruments, 2003). Herein, all velocities and derived flows pertain to "bottom-tracking mode." Comparisons with GPS-derived values have indicated very small differences $(\sim 0.1 \mathrm{~m} / \mathrm{s}$ or less). If both data sets had no errors, differences in velocities at identical locations would quantify the motion of the channel bed. In the present applications, it does not seem probable that the bed was mobile because calculated velocity differences varied randomly across each transect and assumed both positive and negative values. The depth assigned to each ensemble is an average of the four depth values determined by the four sound beams. For generating equal-depth contours (isobaths), however, all four depths are used.

The ADCP surveys were carried out by Water Survey of Canada (WSC) personnel on 11 June 2005 and 12 September 2007. Typically, early June is the period immediately following ice breakup and re-establishment of the openwater condition in East Channel. By this time, the spring flow has already peaked, but it is still much larger than late-summer flows, such as those that occur in September. In 2007, water temperature was measured at six locations across the channel near the deepest area of the SH using a TDR-2050 pressure and temperature transducer. The main objective of this measurement was to verify the uniformity of the temperature field, which is assumed within the ADCP software in order to process data that depend on the speed of sound in water. The measurements fully confirmed this assumption, showing minimal temperature variability $\left(12.2^{\circ} \mathrm{C}\right.$ to $12.3^{\circ} \mathrm{C}$; instrument accuracy $\left.=0.002^{\circ} \mathrm{C}\right)$ throughout the entire depth of the water column ( 0 to $\sim 30 \mathrm{~m})$.

\section{Sidescan Sonar Survey}

In September 2004, the bathymetry of the SH was documented as part of a comprehensive sidescan sonar survey along an extensive reach of East Channel that was carried out by Aquatics Inc. (Calgary, Canada) under a contract with Environment Canada (Beltaos et al., 2011). The entire survey reach was mapped in less than three days. Post 
processing resampled the grid cells to $1 \mathrm{~m} \times 1 \mathrm{~m}$ resolution in $3.5 \mathrm{~km} \times 3.5 \mathrm{~km}$ tiles to facilitate analysis. The survey vessel could not access shallow areas $(<1 \mathrm{~m}$ deep).

\section{Bed Material Sampling}

Detailed data on bed material size distribution in the SH area were reported by Fassnacht (1993) and Fassnacht and Conly (2000). Samples were obtained using Shipek and BM-54 samplers, which grab bed material to depths of $\sim 10 \mathrm{~cm}$ and $5 \mathrm{~cm}$, respectively. In the present study, a drop-weight sediment corer (diameter $\sim 7.6 \mathrm{~cm}$ ) was used in order to minimize sample disturbance and to examine sediment composition beneath the bed surface. The size distribution of bed material particles provides a partial indication of the erodibility of the channel bed. Changes in the distribution with depth could enhance or reduce erodibility and thus influence the depth and mobility of the SH. The retrieved cores varied in length from 15 to $70 \mathrm{~cm}$, depending on the hardness of the bed. In several instances, the corer could not penetrate at all despite the use of 50-pound weights $(220 \mathrm{~N})$.

Size distributions were obtained by a combination of sieve and sedigraph analyses. The procedure consisted of splitting each sample to obtain a representative sub-sample of 5 to $8 \mathrm{gm}$ of sediment, dispersing the sample in sodium metaphosphate and mixing for 15 minutes, passing the wet sample through a sieve with $0.063 \mathrm{~mm}$ opening to separate the gravel and sand fractions from the silt and clay fractions, and analyzing the suspension that passed the $0.063 \mathrm{~mm}$ sieve using a SediGraph Analyzer (described in more detail by Duncan and LaHaie, 1979).

\section{Cs-137 Content}

Caesium-137 is an artificial radionuclide with a half-life of 30.2 years, which was released to the stratosphere in the 1950s and 1960s during testing of thermonuclear weapons. Global fallout began in 1954, peaked in the early 1960s, and decreased to near zero levels in the 1980s. The fallout can be considered spatially uniform, especially over a relatively small area such as the size of a river basin. Upon reaching the catchment surface, Cs-137 was rapidly adsorbed by the soil and accumulated at or near the soil surface. Therefore, presence of Cs-137 in a bed sediment sample would indicate that the sediment likely originated from the soil surface of a watershed (Krishnappan et al., 2009). Concentrations in bed material samples were determined by means of a Gamma Ray Spectrometer, manufactured by Canberra Industries Ltd. The top and bottom slices of each bed material core were analyzed in this manner, but all results were negative, i.e., none of the tested samples contained Cs-137.

\section{Water Surface Elevation in Scour Hole Area}

In order to compare different bathymetric surveys (1985, $1992,2004,2005,2007)$, which provide only depth below the water surface, it is necessary to allow for differences in the respective water surface elevations. This is not an easy task for the Mackenzie Delta, where there are very few geodetic monuments and the delta surface is subject to subsidence (Forbes et al., 2007). As the various surveys were referenced to different temporary benchmarks, three approximate methods were applied to estimate water level differences (all referred to 23 July 1992):

a) assume that, within the range of observations, the water level at the SH is linearly related to the water level at Inuvik;

b) linearly interpolate between gauge readings at Inuvik (WSC hydrometric station 10LC002) and at East Channel entrance (WSC hydrometric station 10LC015) on the basis of channel distances to the $\mathrm{SH}$; and

c) use pressure logger data obtained for a different study in the spring of 2008 near the SH (Beltaos and Carter, 2009) to establish a correlation between SH and Inuvik water levels, assuming that both become equal to zero at zero flow.

All three methods gave very similar results (to within $0.1 \mathrm{~m}$ ), providing reasonable confidence in the bathymetric comparisons that are discussed later. The estimated geodetic elevations of the SH water levels on different survey dates are listed in Table 1 along with ancillary data. Also of interest in Table 1 is that the water surface slope between the SH and Inuvik increases with increasing discharge. This is a hydraulic effect, resulting from the relative proximity to the channel outlet in the Beaufort Sea (Beltaos, 2011).

\section{Horizontal Positioning of Bathymetric Surveys}

Considerable discrepancies in UTM coordinates were noticed between the earlier $(1985,1992)$ and the later $(2004$, 2005) surveys upon plotting the corresponding channel planforms, which were identical in shape but shifted spatially. This is the result of differences in datum, that is, NAD27 (North American Datum 1927) versus WGS84 (World Geodetic System 1984). Full coincidence was achieved via a trial-and-error process resulting in corrections of $-107 \mathrm{~m}$ and $158 \mathrm{~m}$ to the 1985 and 1992 eastings and northings, respectively. These corrections can be compared to mathematically predicted NAD27 to WGS84 shifts of $-107 \mathrm{~m}$ and $172 \mathrm{~m}$, respectively, which were generated by the Geodetic Survey Division (NRCan) algorithm, NTv2 (GSD, 2011).

\section{RESULTS}

\section{Bed Material Composition}

Each core was subdivided into slices 5 to $10 \mathrm{~cm}$ thick, and bed material size analysis was performed on samples taken from each layer. Gravel was encountered in only 
$186 \cdot$ S. BELTAOS et al.

TABLE 1. Water surface elevations and flows on the dates of SH bathymetric surveys.

\begin{tabular}{|c|c|c|c|c|c|}
\hline Date of survey & $\begin{array}{l}\text { Nater surface elevation } \\
\quad \text { at Inuvik (m) }\end{array}$ & Flow at Inuvik $\left(\mathrm{m}^{3} / \mathrm{s}\right)$ & $\begin{array}{l}\text { Estimated water surface } \\
\text { elevation at } \mathrm{SH}(\mathrm{m})^{2}\end{array}$ & Flow at $\mathrm{SH}\left(\mathrm{m}^{3} / \mathrm{s}\right)$ & $\begin{array}{l}\text { Water surface slope, } \\
\text { SH to Inuvik }(\mathrm{m} / \mathrm{km})\end{array}$ \\
\hline 8 August 1985 & 1.27 & 205 & 1.77 & NA & 0.021 \\
\hline 23 July 1992 & 1.85 & 311 & 2.51 & NA & 0.027 \\
\hline 7 September 2004 & 0.81 & 140 & 1.17 & NA & 0.015 \\
\hline 11 June 2005 & 3.03 & 520 & 3.89 & 723 & 0.035 \\
\hline 12 September 2007 & 1.03 & 169 & 1.46 & 185 & 0.018 \\
\hline
\end{tabular}

${ }^{1}$ WSC (2011) data.

${ }^{2}$ Elevation based on differential GPS applications and use of CGG05 (Canadian Gravimetric Geoid 2005).

one sample $(1.8 \%$; slice $5-10 \mathrm{~cm}$ below the surface of the bed). The results indicated that particle size was highly variable from site to site, with median size $\left(\mathrm{D}_{50}\right)$ for the top bed layer ranging from $\sim 8$ to $\sim 230 \mu \mathrm{m}$. This variability is further illustrated in Figure 3, which shows the sand-siltclay fractions for the top layer. No consistent variation of particle size with depth could be discerned, as illustrated in Figure 4. Six of the 13 cores showed no trend while particle size decreased with depth in four cores and increased in three.

The clay fraction (up to $3.9 \mu \mathrm{m}$ ) of the surface layer (Fig. 3) averages $\sim 21 \%$ while the silt-plus-clay content is often high, suggesting potential for cohesive resistance to bed material mobilization by flow shear stresses. This resistance could help explain the very steep walls of the $\mathrm{SH}$, especially on the upstream side (see also next subsection). Large channel-boundary slopes have also been found elsewhere in the delta (Hollingshead and Rundquist, 1977). These authors cited evidence indicating that soil strata near bed level are highly overconsolidated, which could also account for the difficulty encountered in obtaining bed material cores.

The data of Fassnacht and Conly (2000) exhibited spatial variability similar to that shown in Figure 3, but indicated somewhat lower clay portions (average $\sim 16 \%$ over the same area that was covered by the present data). The particle size was slightly larger (average $D_{50}=83.2 \mu \mathrm{m}$, as opposed to $75.5 \mu \mathrm{m}$ for the present data). The small discrepancies could be due to differences in sampling methods (grab samplers vs. corers) and possibly in analytical techniques. Fassnacht and Conly (2000) did not mention the silt-clay boundary used in their sediment size analyses, but a value of $4 \mu \mathrm{m}$ is indicated in Fassnacht (1993), where the raw data are presented in detail.

\section{Scour Hole Surveys}

The study reach contains the scour hole area as well as entry and exit segments, for a total length of $600 \mathrm{~m}$. Figure 5 shows the GPS-derived plan view of the 2005 boat track and transects in terms of latitude and longitude. Though every effort was made to maintain a straight course for each transect, Figure 5 indicates that the actual boat trajectories were curvilinear. Strong turbulence, presence of shear zones, and flow reversals were contributing factors. The boat track commenced near the left bank at transect 0 and ended at the right bank of transect 16, following the direction of the arrows. The numbers 10 and 12 do not appear in Figure 5 because they did not represent actual survey transects. The detailed bathymetric data were processed to obtain the isobaths shown in Figure 6 using the contour plot function (contour.m) in MATLAB.

The 2007 survey was intended to repeat the measurements at the 2005 transects or as close to them as possible. Unfortunately, the GPS system malfunctioned in 2007, so it is not possible to generate a boat-track plot or to locate the corresponding transects on a UTM grid. One can still determine the maximum depth of the hole by examining the detailed data from the various transects, but its precise location is unknown.

\section{Discharge Determinations}

The final output of an ADCP transect survey is the river discharge, which is obtained by integrating ensemble velocities and the resulting panel flows across the stream. Salient data for the 2005 run are presented in Table 2. It is evident that the flow values obtained in the first six transects ( 0 to 6 ), all located within the relatively straight entry channel (Fig. 5), are highly consistent among themselves, averaging $723 \mathrm{~m}^{3} / \mathrm{s}$. The same applies to the three transects of the exit reach (14 to 16), but not to the transects located in the scour hole area $(6$ to $9,11,13)$. Here, the ADCP-indicated flow values range from a low of 505 to a high of $797 \mathrm{~m}^{3} / \mathrm{s}$. The large variability was most likely caused by the highly threedimensional and irregular nature of the velocity field in this area, which included reverse flows and shear zones (see also later discussion). Mean velocity (discharge over crosssectional area) is calculated on the basis of the more reliable figure of $723 \mathrm{~m}^{3} / \mathrm{s}$ and is seen to decrease from entry-reach values of $\sim 0.6 \mathrm{~m} / \mathrm{s}$ to $\sim 0.2 \mathrm{~m} / \mathrm{s}$ in the $\mathrm{SH}$ reach, where the cross-sectional area is three times as great.

Very similar considerations apply to the 2007 data set: entry-reach mean velocities were $\sim 0.25 \mathrm{~m} / \mathrm{s}$, while those over the scour hole dropped to as low as $0.05 \mathrm{~m} / \mathrm{s}$. As will be shown later, however, mean velocity is not a good index of actual velocity magnitude within the SH reach, owing to flow reversals. On both occasions (2005 and 2007), the 


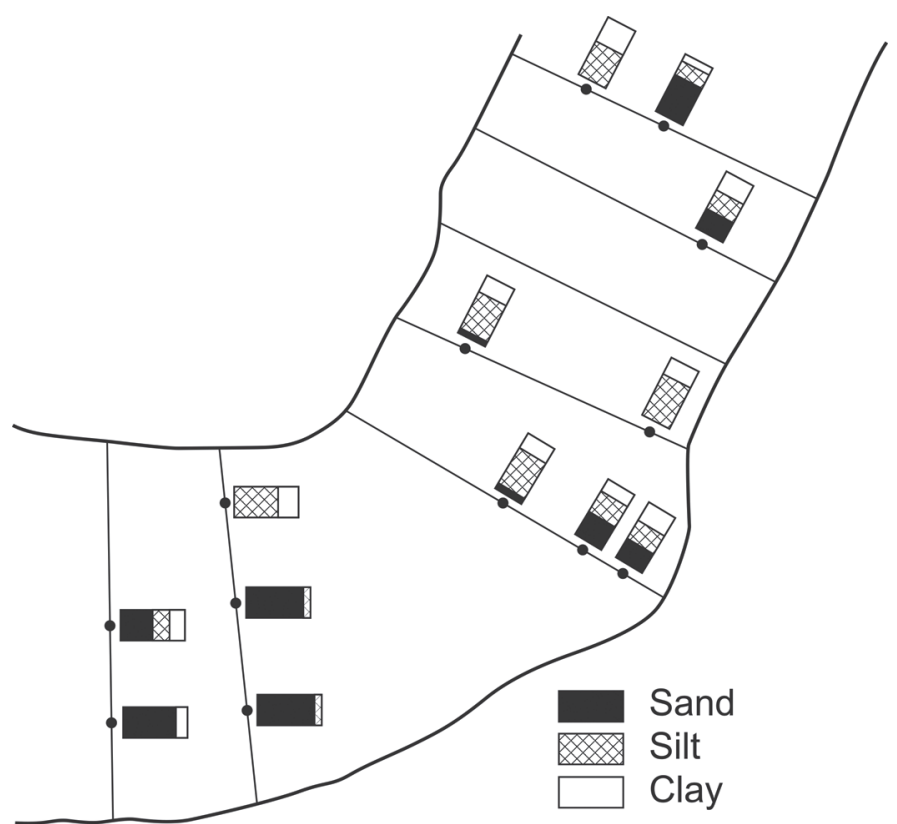

FIG. 3. Spatial variability of sand, silt, and clay fractions in the top layer of the bed.

measured flows were higher than the corresponding flows at Inuvik (Table 1), as determined from the rating table of the local WSC gauge (Hydrometric Station No. 10LC002).

\section{Structure of Velocity Field, June 11, 2005}

One limitation of the ADCP is that it cannot measure flow velocity within narrow strips along the channel bed and water surface. The bottom strip has a height of $6 \%$ of the local flow depth (Gordon, 1996), whereas the top strip has a height of $\sim 0.9 \mathrm{~m}$ (RD Instruments, 2003). In the present applications, this latter height was $0.83 \mathrm{~m}$ for the 2005 run and $0.82 \mathrm{~m}$ for 2007 . Consequently, the middle points of the first bins under the transducer were located 1.08 and $1.07 \mathrm{~m}$ below the water surface. All data presented below pertain to the 2005 survey. Similar results were obtained in 2007, but flow velocities were considerably smaller, owing to the much lower discharge $\left(185 \mathrm{~m}^{3} / \mathrm{s}\right.$ in 2007 , as opposed to $723 \mathrm{~m}^{3} / \mathrm{s}$ in 2005).

The three-dimensional field of "streamwise" velocity is depicted in Figure 7. Here, the "streamwise" direction is the mean flow direction within a given transect, as determined by the ADCP software. No-data strips near the water surface and next to the channel bed are clearly indicated. The velocity field is fairly uniform within the entry reach, which is well represented by transect 4 . Transect 6 is near the beginning of the $\mathrm{SH}$ area, and already shows increased channel depth, as well as some flow reversals near the right bank (blue tones). Channel depth increases as one progresses downstream into the main $\mathrm{SH}$ area, while flow reversal zones are evident near both banks (transects $7-11)$. In this region, there are also zones where both positive and negative velocities occur within the same vertical. Flow reversals essentially disappear by transect 13: here,

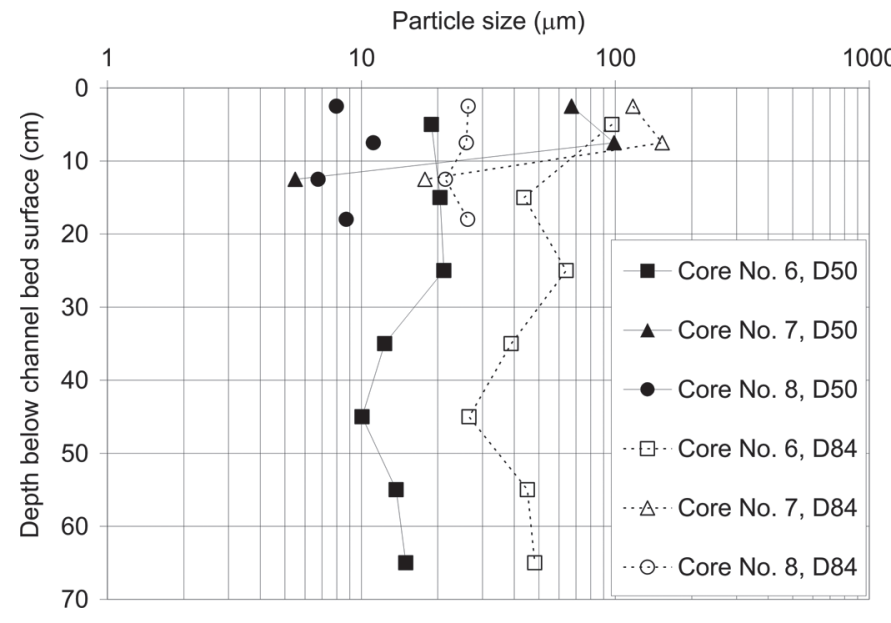

FIG. 4. Example of bed material size variation with depth. Cores 6, 7, 8 were located at $\sim 1 / 8,1 / 4$, and 1/2 of channel width from the Left (East) Bank, respectively.

the forward flow in the mid-channel zone is relatively weak, and isolated negative values are very likely caused by turbulent fluctuations. Though not shown here, similar plots of transverse and vertical velocity components indicate increased intensity of secondary currents in the SH area, especially near the reversal zones.

As noted earlier, the mean velocity of the relatively uniform entry-reach flow is $\sim 0.6 \mathrm{~m} / \mathrm{s}$ whereas it drops to as low as $0.2 \mathrm{~m} / \mathrm{s}$ in the hole area, with corresponding differences for 2007 (Table 2). However, because the mean velocity derives from algebraic summation of forward and reverse flows, it is not representative of velocity magnitude where there is flow reversal. This fact is aptly illustrated in Figure 7: the predominant magnitude of forward velocity (green tones) is $\sim 0.5 \mathrm{~m} / \mathrm{s}$ throughout the study reach, including the SH area. Reverse velocities (blue tones) in the $\mathrm{SH}$ area are of similar magnitude.

Within the ADCP system, vertical profiles of velocity are called "ensembles" and may contain data from one or more "pings," depending on user settings. In the present application, there was a single ping per ensemble, so that each ensemble may be regarded as an instantaneous profile of spatially averaged velocities over successive bins (Figs. 8a to 8c). Though the spatial averaging subdues some of the scatter, it is evident that strong turbulence was present. Moreover, Figure 8a illustrates the relatively wellbehaved velocity distribution in the entry channel upstream of the SH (transect 0) and the presence of reverse flow zones within the SH area (transects 8 and 11). Figures $8 \mathrm{~b}$ and $8 \mathrm{c}$ illustrate transverse and vertical velocity components, respectively. These components are seen to fluctuate around zero within the relatively straight entry reach (transect 0 ), but they exhibit significant non-zero values in the $\mathrm{SH}$ area (transects $7,8,11$ ), indicating strong eddying motions and secondary currents.

Close inspection of Figure 7 shows that the boundaries separating forward and reverse flows are not vertical, but occur at different distances from the banks as the depth 


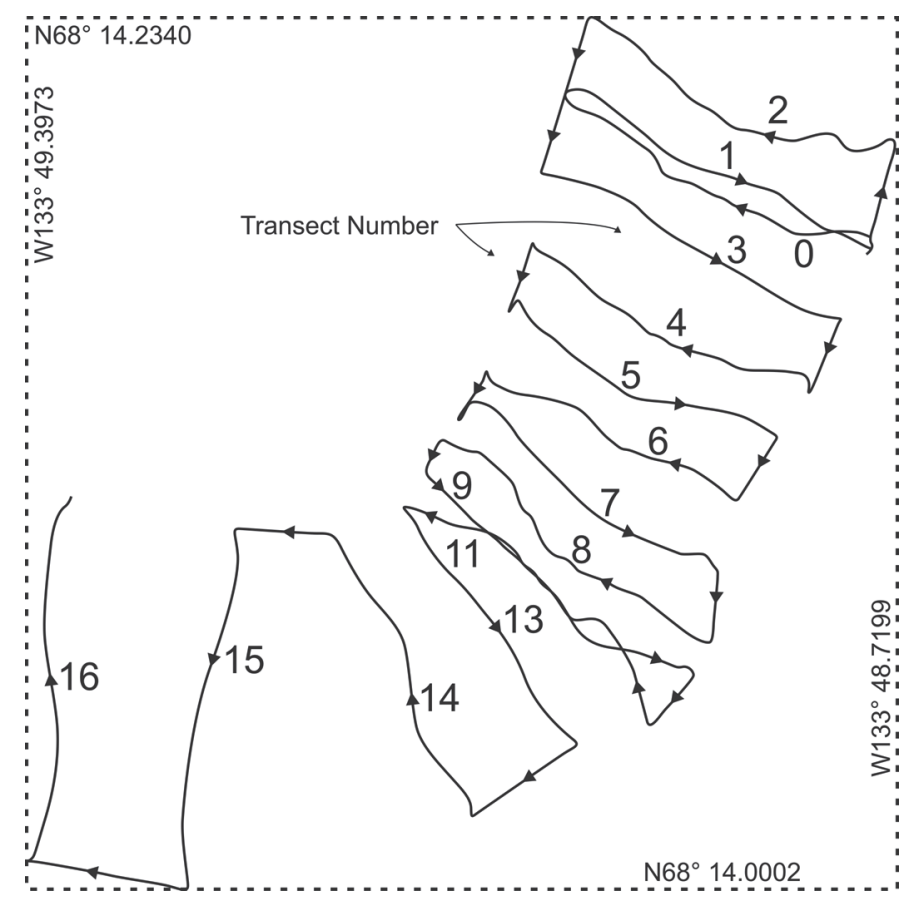

FIG. 5. Plan view of boat track and actual transect shapes, ADCP survey, June 2005.

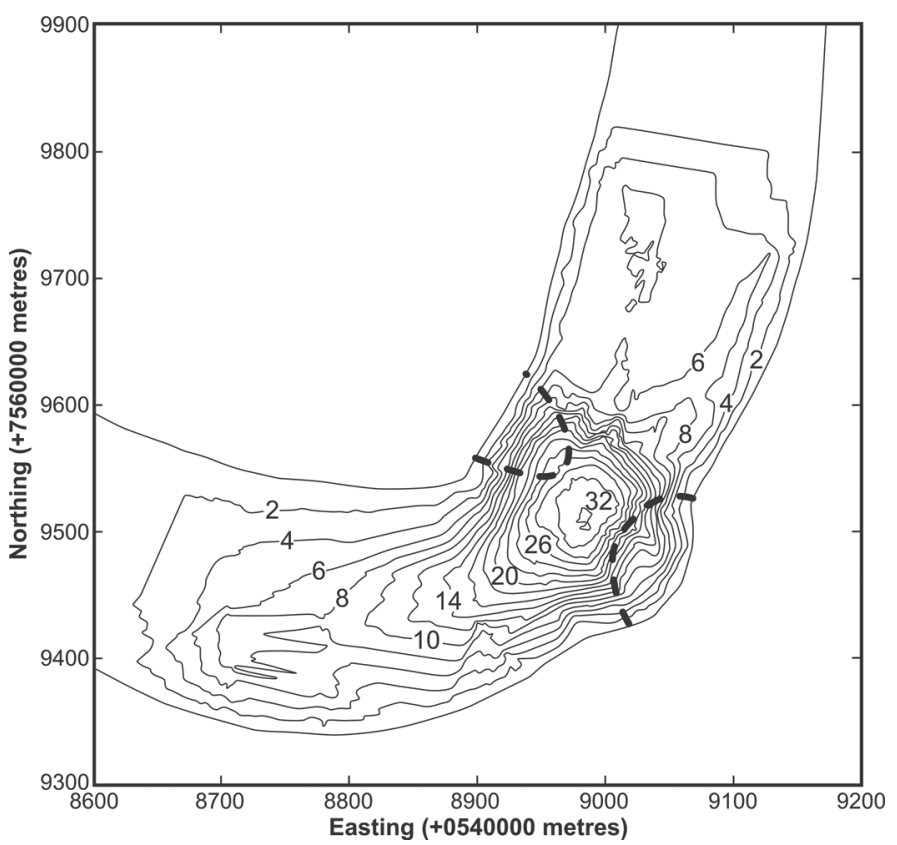

FIG. 6. Bathymetry of the East Channel scour hole, as measured by the ADCP on 11 June 2005. The dashed lines indicate approximate limits of reverse-flow areas near the channel banks.

TABLE 2. Summary data from ADCP runs of 11 June 2005.

\begin{tabular}{|c|c|c|c|c|c|c|c|}
\hline $\begin{array}{l}\text { Transect } \\
\text { number }\end{array}$ & $\begin{array}{l}\text { Number of } \\
\text { ensembles }\end{array}$ & $\begin{array}{l}\text { Discharge } \\
\mathrm{m}^{3} / \mathrm{s}\end{array}$ & $\begin{array}{c}\text { Area } \\
\left(\mathrm{m}^{2}\right)\end{array}$ & $\begin{array}{l}\text { Width } \\
\text { (m) }\end{array}$ & $\begin{array}{l}\text { Mean depth } \\
(\mathrm{m})\end{array}$ & $\begin{array}{l}\text { Max. depth } \\
\text { (m) }\end{array}$ & $\begin{array}{l}\text { Mean velocity } \\
(\mathrm{m} / \mathrm{s})^{1}\end{array}$ \\
\hline 0 & 577 & 718 & 1147 & 192 & 6.0 & 8.6 & 0.63 \\
\hline 1 & 428 & 724 & 1134 & 193 & 5.9 & 8.6 & 0.64 \\
\hline 2 & 749 & 726 & 1110 & 189 & 5.9 & 7.6 & 0.65 \\
\hline 3 & 498 & 725 & 1133 & 189 & 6.0 & 9.1 & 0.64 \\
\hline 4 & 788 & 723 & 1140 & 179 & 6.4 & 8.6 & 0.63 \\
\hline 5 & 474 & 723 & 1245 & 172 & 7.2 & 10.6 & 0.58 \\
\hline 6 & 634 & 797 & 1751 & 164 & 10.7 & 15.6 & 0.41 \\
\hline 7 & 453 & 606 & 3268 & 170 & 19.2 & 31.1 & 0.22 \\
\hline 8 & 609 & 518 & 3796 & 187 & 20.3 & 32.6 & 0.19 \\
\hline 9 & 446 & 668 & 3409 & 187 & 18.2 & 31.6 & 0.21 \\
\hline 11 & 604 & 505 & 3324 & 180 & 18.5 & 32.1 & 0.22 \\
\hline 13 & 339 & 625 & 2361 & 166 & 14.2 & 26.1 & 0.31 \\
\hline 14 & 444 & 711 & 1679 & 176 & 9.5 & 17.6 & 0.43 \\
\hline 15 & 454 & 694 & 1286 & 196 & 6.6 & 9.6 & 0.56 \\
\hline 16 & 581 & 704 & 1233 & 202 & 6.1 & 10.6 & 0.59 \\
\hline
\end{tabular}

${ }^{1}$ Calculated for a flow of $723 \mathrm{~m}^{3} / \mathrm{s}$.

changes. Considering "average" distances at different transects, the approximate horizontal extent of reverse-flow areas is depicted in Figure 6, where isobaths are also shown. It is evident that the approach flow is directed towards the deepest area of the $\mathrm{SH}$ when it reaches the edge of the steep upstream side of the hole.

As noted earlier, similar results were obtained in 2007: the main difference was that velocity magnitudes were smaller, owing to the much lower flow on 12 September 2007. Even at such reduced velocities (and thus turbulence levels), the flow was capable of complete mixing, as evinced by the previously described homogeneity of the water temperature field.

\section{SCOUR HOLE STABILITY}

As it was not possible to find any control points that were used in the 1985 and 1992 surveys, the best way to compare all four bathymetric surveys is by examining bottom elevations and isobaths, after correcting for differences in horizontal datum and water level. Table 3 indicates that the minimum bed elevation has remained practically unchanged $(-28.2 \mathrm{~m},-28.1 \mathrm{~m})$ between 1985 and 2007. The 1992 departure from these values cannot be explained by sounding error $(\sim 2 \%$ for a downward-looking ADCP; Ganju et al., 2005) and hints at a dynamic type of stability via occurrence of alternating erosion and deposition events. 


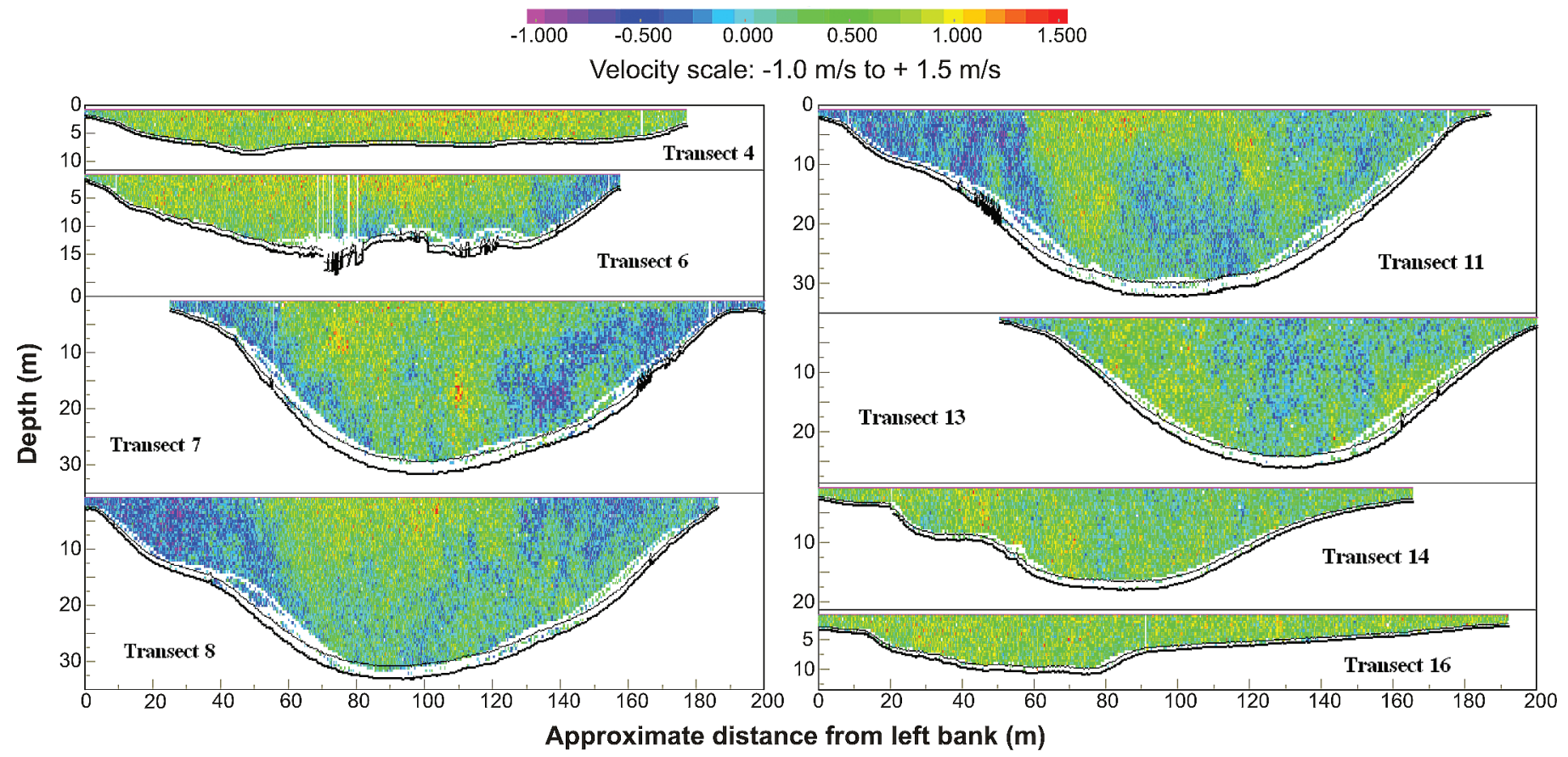

FIG. 7. Cross-sectional geometry and streamwise velocity component along the study reach, 11 June 2005. Note zones of reverse flow (blue tones) in scour hole area (transects 6 to 14). Transect views are for an observer facing downstream.

A detailed comparison of bathymetries is illustrated in the series of plots of Figure 9 and shows that the SH has remained largely unchanged during the period 1985 to 2005. Upon comparing individual isobaths of any one pair of surveys in Figure 9, small areas of erosion and deposition become apparent. These areas also suggest dynamic stability, though they could be partly attributed to observational uncertainties arising from sounding or horizontal positioning errors (GPS systems used in the 2004 and 2005 surveys; acoustic distance-measuring devices in 1985 and 1992).

Because the earlier $(1985,1992)$ and later $(2004,2005)$ surveys involved differences in horizontal datum, UTM coordinates were adjusted so as to match channel boundaries, as described earlier. Strictly speaking, therefore, the preceding findings indicate that the $\mathrm{SH}$ is stable relative to the channel boundaries, but do not preclude simultaneous and identical migrations of both the channel and the SH. Lapointe's (1986b) "migration-rates map" (1950 to 1984) indicates a peak rate of $0.7 \mathrm{~m} / \mathrm{yr}$ near the apex of the $180^{\circ}$ bend (Fig. 2) that is located some $500 \mathrm{~m}$ downstream of the SH. The peak values apply to migration zones that typically extend from slightly upstream to some distance downstream of the apex. Considering the large distance between the apex and the $\mathrm{SH}$, it is unlikely that the latter has been subject to discernible migration in recent decades. A comparison between the (NTv2-shifted) 1992 survey and a recently georeferenced air photo, taken in 2004 under MVAP (NWT Centre for Geomatics, 2011), indicated little change in the channel boundaries at the SH site. Downstream of the $\mathrm{SH}$, deposition and erosion $(\sim 10 \mathrm{~m})$ were indicated along the inner and outer banks, respectively.
The stability of the channel in the SH area is corroborated by the experience of the owner of a nearby summer cabin (William Modeste, pers. comm. 2010, 2011). No change has been noticed in the location of the "whirlpool" or of the water's edge relative to the cabin over the past $20+$ years, even though the top of the initially near-vertical bank has moved inland by some 5 to $6 \mathrm{~m}$ via flood-induced slumping. In the spring of 2011, heavy bank erosion occurred at various East Channel fishing camps, which are located near scour holes. In the study area, the erosion occurred near the apex of the bend downstream of the $\mathrm{SH}$ (Fig. 2).

\section{DISCUSSION}

The present data on the flow structure have indicated that neither velocity magnitude nor turbulence diminishes substantially over the scour hole. This results from the formation of eddies near both banks and the consequent reduction of the "live-stream" cross-sectional area. Even within the central areas of eddy zones, where the near-bed velocity is close to zero, turbulence remains undiminished (Fig. 8a, b). These features suggest that the scour hole is hydraulically maintained, as postulated by Fassnacht and Conly (2000).

For a more detailed and quantitative explanation of $\mathrm{SH}$ stability, one would have to consider the erosive capacity of the flow (indexed by the bed shear stress, $\tau_{b}$ ) relative to the resistance of the bed to erosion (indexed by the critical shear stress for erosion, $\tau_{\mathrm{e}}$ ). Because ADCP velocity data do not extend to the channel bed, it would be difficult to assess 


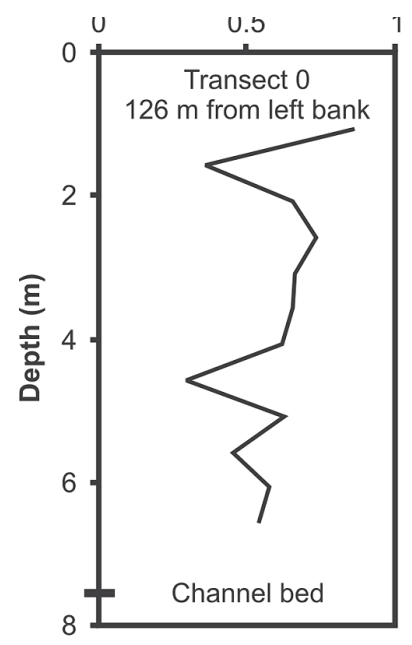

(a)
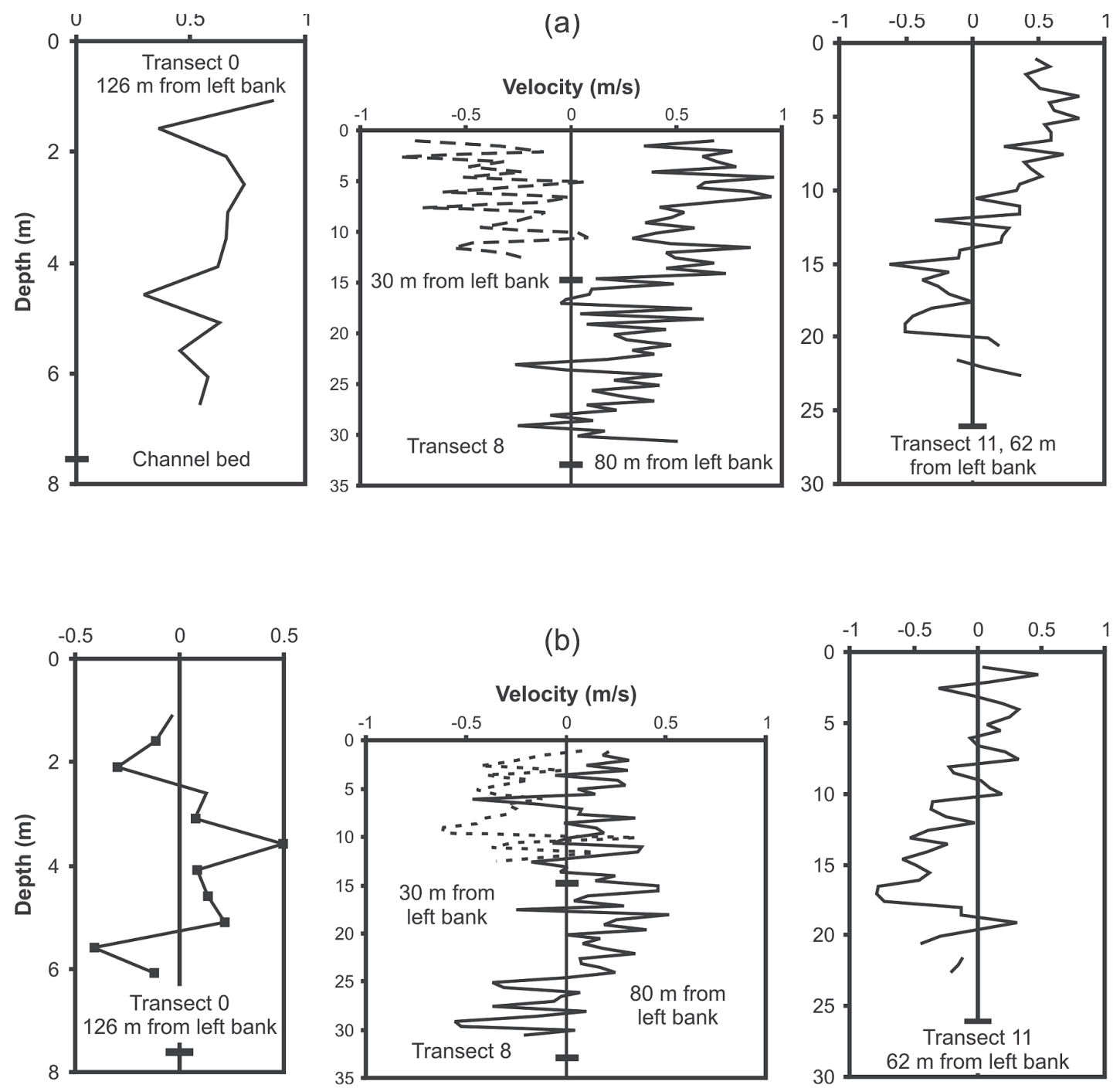

(b)
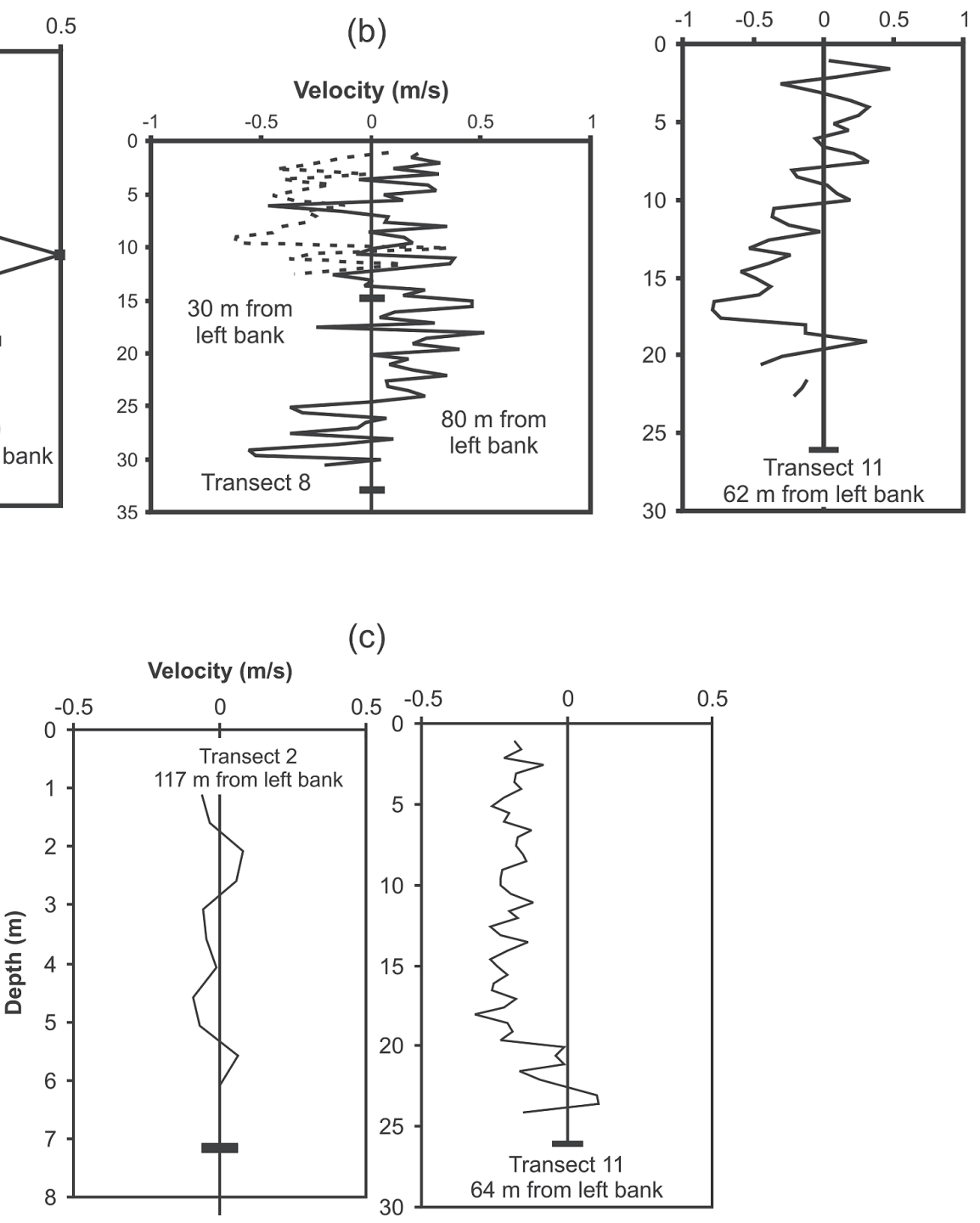

FIG. 8. (a) Vertical profiles of streamwise velocity component, obtained by summing the projections of measured north and east components onto the mean flow direction within each transect, 11 June 2005. (b) Vertical profiles of transverse velocity component, obtained by summing the projections of measured north and east components onto a perpendicular to the mean flow direction within each transect, 11 June 2005. Positive values indicate flow towards the Left Bank. (c) Vertical profiles of upward velocity component, 11 June 2005. 
TABLE 3. Elevations of lowest points in the SH area, as measured during different surveys.

\begin{tabular}{lccc}
\hline \hline Date of survey & Flow at Inuvik $\left(\mathrm{m}^{3} / \mathrm{s}\right)$ & $\begin{array}{c}\text { Estimated water surface } \\
\text { elevation at scour hole }(\mathrm{m})\end{array}$ & Minimum bed elevation (m) \\
\hline 8 August 1985 & 205 & 1.77 & -28.2 \\
23 July 1992 & 311 & 2.51 & -26.5 \\
7 September 2004 & 140 & 1.17 & -28.1 \\
11 June 2005 & 520 & 3.89 & -28.7 \\
12 September 2007 & 169 & 1.46 & -28.1 \\
\hline \hline
\end{tabular}

the bed shear stress using the well-known logarithmic law because it is the velocity variation within the near-bed layer that controls the shear stress. An additional problem is that velocity profiles within the $\mathrm{SH}$ area are often influenced by flow separation and reversal, so that the logarithmic law might often not apply. As an alternative, approximate shear stress values were determined by means of the computational (3-D) fluid dynamic model FLUENT, which was calibrated against measured (2005) velocities (Gharabaghi et al., 2007).

Table 4 summarizes the results of the modeling and includes frequency estimates of the modeled discharges. To estimate flow at the SH, a linear relationship with the simultaneous flow at Inuvik was assumed from the two available data pairs (Table 1). Very low or nil shear stresses occur at the centres of the eddy zones in the SH area. Within the live-stream area, the shear stress remains comparable to the stresses occurring in the upstream and downstream reaches, which is consistent with the velocity/turbulence structure deduced from the ADCP measurements. Modeling of flows under a sheet ice cover (Inkratas et al., 2009) indicated lower bed shear stresses for flows ranging from 500 to $1000 \mathrm{~m}^{3} / \mathrm{s}$.

For a cohesionless bed with median particle size of $\sim 75 \mu \mathrm{m}$ (average $\mathrm{D}_{50}$ of bed surface samples), the critical shear stress for erosion $\left(\tau_{\mathrm{e}}\right)$ is $\sim 0.2 \mathrm{~Pa}$ (Gharabaghi et al., 2007), which is generally less than the values indicated in Table 4. As noted earlier, however, the bed material likely exhibits cohesion; therefore, the value of $\tau_{\mathrm{e}}$ in the study reach may be different.

There is a large body of literature on the critical shear stress for erosion of cohesive channel beds. Various measurements and prediction formulae exhibit extreme variability (Zhu et al., 2008), which partly results from differences in how the critical shear stress is defined and measured. For example, the "average" bed material composition within the study reach ( $41.2 \%$ sand, $37.4 \%$ silt, $21.4 \%$ clay) could indicate $\tau_{\mathrm{e}}$ values that range from 0.7 to $23 \mathrm{~Pa}$ (Dunn, 1959; Smerdon and Beasley, 1961; Kamphuis et al., 1990; Navarro, 2004). The data in Table 4 suggest that the bed of East Channel in the vicinity of the SH could not be mobilized, even at very high flows, if $\tau_{\mathrm{e}}$ were to exceed some $2 \mathrm{~Pa}$. This situation would result in a static type of stability, involving neither erosion nor deposition.

However, more recent measurements suggest that the lower range is much more likely (Krishnappan, 2000, 2007). When cohesive sediment is mobilized, erosion and

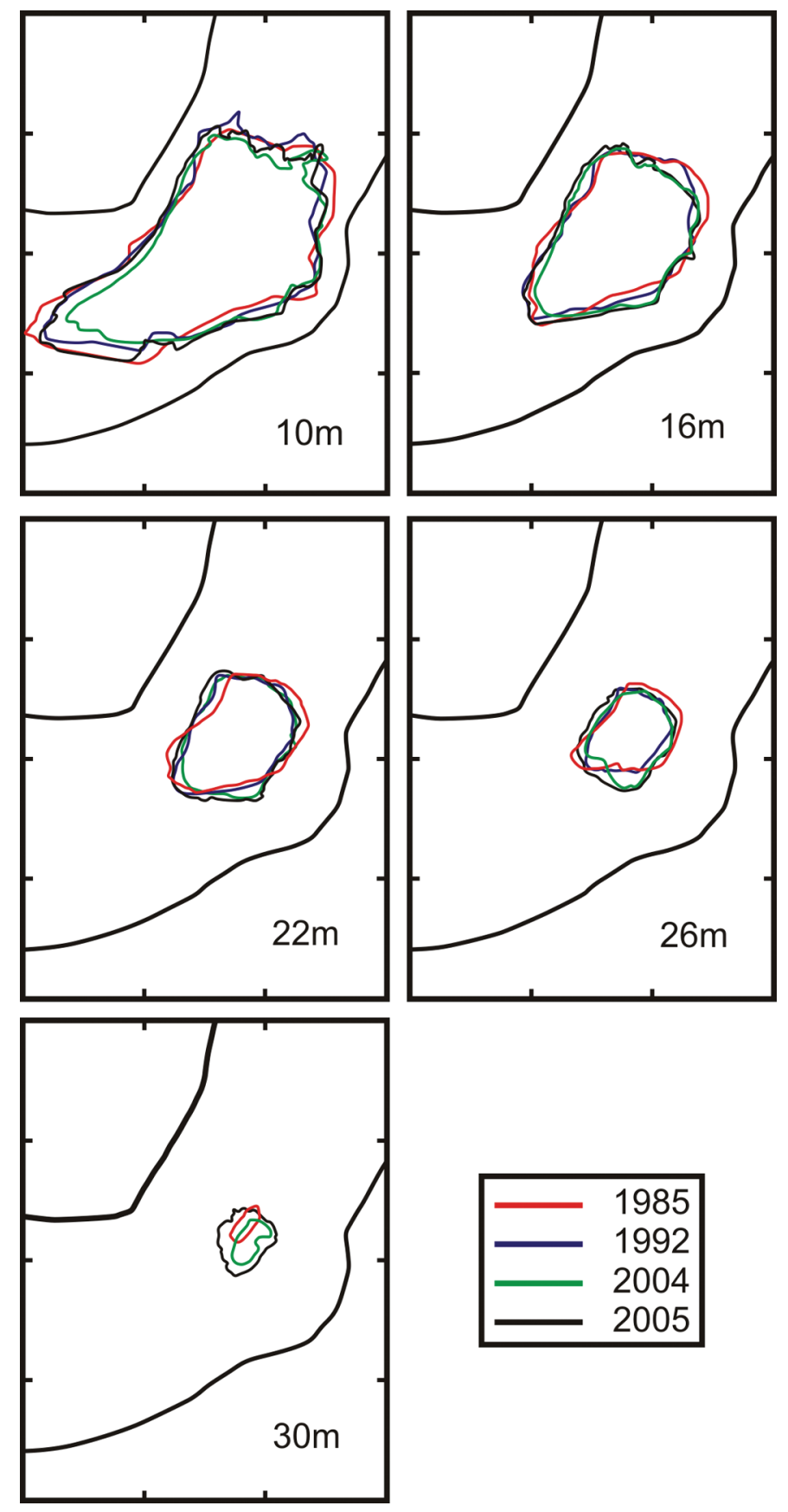

FIG. 9. Isobath comparisons of four different surveys. All depths are referred to the 1992 water level (approx. geodetic elevation $=2.51 \mathrm{~m}$, per Table 1).

deposition processes do not occur simultaneously for all shear stresses, as they do with cohesionless bed sediments. 
$192 \cdot$ S. BELTAOS et al.

TABLE 4. Computed bed shear stress at different open-water flow conditions; data from Gharabaghi et al. (2007).

\begin{tabular}{|c|c|c|c|}
\hline \multirow[b]{2}{*}{ Flow condition } & \multicolumn{3}{|c|}{ Magnitude of bed shear stress $\left(\mathrm{N} / \mathrm{m}^{2}\right.$ or $\left.\mathrm{Pa}\right)$} \\
\hline & Upstream of SH area & SH area & Downstream of SH area \\
\hline $720 \mathrm{~m}^{3} / \mathrm{s}$ measured flow, 11 June 2005 ; exceeded almost annually (once in 1.3 years) & $0.3-0.6$ & $0.0-0.3$ & $0.2-0.4$ \\
\hline $1000 \mathrm{~m}^{3} / \mathrm{s} ;$ exceeded once in $\sim 3$ years $^{1}$ & $0.6-1.2$ & $0.0-0.9$ & $0.3-0.6$ \\
\hline $1400 \mathrm{~m}^{3} / \mathrm{s} ;$ exceeded once in $\sim 17$ years $^{1}$ & $0.7-1.3$ & $0.0-0.9$ & $0.5-1.0$ \\
\hline
\end{tabular}

${ }^{1}$ Estimates based on correlation with WSC hydrometric station data at Inuvik (1974-2008).

Therefore, critical conditions have been identified for both erosion and deposition (Partheniades, 1962; Mehta and Partheniades, 1975; Parchure, 1984; Lau and Krishnappan, 1994). The critical shear stress for deposition $\left(\tau_{\mathrm{d}}\right)$ was first defined by Partheniades (1962) as the shear stress below which all of the initially suspended sediment will deposit. Milburn and Krishnappan (2003) measured the value of $\tau_{\mathrm{d}}$ for fine sediment in Hay River, Northwest Territories, Canada, as $0.08 \mathrm{~Pa}$. The critical shear stress for erosion is higher than $\tau_{\mathrm{d}}$ : measurements on bed sediments of the Hay River indicated that $\tau_{\mathrm{e}}$ is $\sim 2$ times $\tau_{\mathrm{d}}$ (Milburn and Krishnappan, 2003). Even though the critical shear stresses for deposition and erosion of cohesive sediment are site-specific and depend on a number of governing parameters, these values can be used as rough estimates for the fine sediment near the SH. If $\tau_{\mathrm{d}}$ is taken as $0.1 \mathrm{~Pa}$, then $\tau_{\mathrm{e}}$ would be $\sim 0.2 \mathrm{~Pa}$, which would indicate large-scale bed material mobilization and transport at all flows (Table 4). It is probable then, that the fine sediment carried by the approaching flow in suspension does not deposit over the SH because local shear stresses are higher than the critical stress for deposition $\tau_{\mathrm{d}}$ (Table 4). Even if there were some deposition in the central part of the $\mathrm{SH}$, this sediment would be re-suspended by a higher flow because the critical stress for erosion $\tau_{\mathrm{e}}$ is not much higher than $\tau_{\mathrm{d}}$. If erosion of pre-existing bed material (not freshly deposited) in the deeper parts of the SH were prevented by a higher value of $\tau_{\mathrm{e}}$ owing to overconsolidation, the SH bathymetry would attain a state of dynamic stability: small differences in bathymetry would be encountered from year to year, but the SH would remain essentially unchanged over the long term. This scenario is consistent with the results of the bathymetric measurements reported in the previous section, but can be confirmed only by in-situ measurements of the critical shear stress.

In the case of cohesive materials, measurement of the critical shear stress is challenging (Tolhurst et al., 2009): laboratory measurement necessitates disruption of the bed material fabric, while various field devices have considerable limitations, and different results may be obtained from different devices. Nevertheless, it would be of interest to carry out a field program aiming to determine whether the channel bed can be mobilized at certain flows. Such information would not only be relevant to the deep scour holes of the Mackenzie Delta: it would also help in assessing the potential for general and local scour at high flows, particularly under ice jams that may form in some of the distributary channels.
The complete absence of Cs-137 from the channel bed indicates that either overland sediment does not arrive at the study area of East Channel or that any such sediment that does arrive is transported through without deposition or entrapment at the bed. It is difficult at present to determine which alternative applies, but the available evidence suggests that transport-through is probable. Measurements by Droppo et al. (1998) indicate that suspended sediment in the lower Mackenzie, as well as in two major distributaries (Peel Channel, East Channel), consists almost entirely of flocs ( $\sim 99 \%$ by volume) rather than primary particles. The median size of the flocs in East Channel at Inuvik (23 June, 27 July, and 7 September 1993) was less than $23 \mu \mathrm{m}$. According to data presented by Khelifa and Hill (2006), the settling velocity of $23 \mu \mathrm{m}$ flocs ranges from 0.001 to $0.03 \mathrm{~cm} / \mathrm{s}$. These values are extremely small relative to the vertical turbulent fluctuations indicated by the ADCP surveys, which are on the order of $\mathrm{cm} / \mathrm{s}$ at low flow (September 2007). Consequently, the flocs can easily be kept in suspension. The same holds for primary particles $\left(\mathrm{D}_{50}=3.6\right.$ to 5.9 $\mu \mathrm{m}$; Droppo et al., 1998), for which the settling velocity has been calculated as 0.001 to $0.003 \mathrm{~cm} / \mathrm{s}$.

\section{SUMMARY AND CONCLUSIONS}

The results of a field program to study the stability and flow structure in the vicinity of a deep scour hole in East Channel presented in the preceding sections show that, in contrast to normal rivers, the flow at the $\mathrm{SH}$ exceeds the flow at Inuvik, which is located some $23 \mathrm{~km}$ downstream. Uncertainties arising from lack of water surface geodetic elevations have been resolved, and it was shown that the water surface slope between the SH and Inuvik increases with increasing discharge, in accord with delta hydraulic conditions.

The present measurements and analysis conclusively show that the scour hole has maintained its depth and shape at least since 1985. Small discrepancies between isobaths of different years indicate a dynamic stability that involves short-term fluctuations in erosion and deposition, but measurement errors could also account for such fluctuations. The ADCP data set has provided unique insights into the highly three-dimensional velocity field and revealed major eddy structures and flow reversals, which help maintain sizeable velocity magnitudes despite low mean velocities. It was shown that turbulence is sufficient to prevent deposition of 
overland sediment even during low-flow conditions, which explains the absence of Cs-137 from bed core samples in the study reach.

The composition of the bed material suggests cohesive behaviour, which points to typical critical shear for erosion of $\sim 0.2 \mathrm{~Pa}$ or more. The literature is ambiguous in this case, as it indicates a range that spans two orders of magnitude. The low end of the range, which derives from more recent measurements, is considered more likely. Coupled with numerical-model determinations of actual shear stresses, the lower critical-shear values point to a dynamic stability condition. It would be of interest to measure the critical shear using in-situ field devices, not only with respect to the study of deep scour holes, but also to assess the scour potential of high flows and ice jams.

\section{ACKNOWLEDGEMENTS}

Financial support for this study has been provided by the Mackenzie Delta Oil and Gas Environmental Assessment Project, the Canadian component of IPY, and Environment Canada. Dr. Terry Prowse (Water and Climate Impacts Research Centre, Environment Canada and University of Victoria) initiated the 2004 sidescan sonar survey of East Channel, which included bathymetric information on the scour hole. Logistical assistance by the Aurora Research Institute and the Water Survey of Canada is acknowledged with appreciation.

\section{REFERENCES}

Beltaos, S. 2011. Developing winter flow rating relationships using slope-area hydraulics. River Research and Applications 27(9):1076-1089.

Beltaos, S., and Carter, T. 2009. Field studies of ice breakup and jamming in the Mackenzie Delta. Proceedings, 15th Workshop on River Ice, St. John's, Newfoundland and Labrador, 15-17 June 2009. Edmonton: CGU HS Committee on River Ice Processes and the Environment. 266-283.

Beltaos, S., Carter, T., and Prowse, T. 2011. Morphology and genesis of deep scour holes in the Mackenzie Delta. Canadian Journal of Civil Engineering 38(6):638-649.

Black, S., and Fehr A., eds. 2002. Natural history of the Western Arctic. Vancouver: Gordon Soules Book Publishers Ltd.

Burn, C.R., and Kokelj, S.V. 2009. The environment and permafrost of the Mackenzie Delta area. Permafrost and Periglacial Processes 20(2):83-105.

Droppo, I.G., Jeffries, D., Jaskot, C., and Backus, S. 1998. The prevalence of freshwater flocculation in cold regions: A case study from the Mackenzie River Delta, Northwest Territories, Canada. Arctic 51(2):155-164.

Duncan, G.A., and Lahaie, G.G. 1979. Size analysis procedures used in Sedimentology laboratory. Hydraulics Division Manual. Burlington, Ontario: National Water Research Institute.
Dunn, I.S. 1959. Tractive resistance of cohesive channels. Journal of the Soil Mechanics and Foundations Division 85:1-24.

Emmerton, C.A., Lesack, L.F.W., and Marsh, P. 2007. Lake abundance, potential water storage, and habitat distribution in the Mackenzie River Delta, western Canadian Arctic. Water Resources Research 43, WO5419, doi:10.1029/2006WR005139.

Fassnacht, S. 1993. Mackenzie River East Channel scour hole investigations: Project data file. Report C\&P-IWD-93-010, IWD-NWT NOGAP Project C11.6 (Delta Channel Stability). Yellowknife: Inland Waters Directorate and Northern Oil and Gas Program.

Fassnacht, S.R., and Conly, FM. 2000. Persistence of a scour hole in the East Channel of the Mackenzie Delta, N.W.T. Canadian Journal of Civil Engineering 27(4):798-804.

Forbes, D.L., Craymer, M., Henton, J., Herron, T., Kokelj, S., Lapelle, E., Manson, G., et al. 2007. Combining geological, geodetic, and tide-gauge data to estimate coastal subsidence and flooding hazards in the Mackenzie Delta, Western Arctic Canada. American Geophysical Union Fall Meeting, 10-14 December 2007, San Francisco, California. EOS Transactions 88(52), Fall Meeting Supplement, Abstract G51A-0136.

Ganju, N.K., Schoellhamer, D.H., and Bergamaschi, B.A. 2005. Suspended sediment fluxes in a tidal wetland: Measurement, controlling factors, and error analysis. Estuaries 28(6):812 -822.

Gharabaghi, B., Inkratas, C., Beltaos, S., and Krishnappan, B. 2007. Modelling of 3D flow velocities in a deep hole in the East Channel of the Mackenzie Delta, N.W.T. Canadian Journal of Civil Engineering 34(10):1312-1323.

Gordon, R.L. 1996. Acoustic Doppler current profiler principles of operation: A practical primer, 2nd ed. for broadband ADCPs. San Diego: RD Instruments.

GSD (Geodetic Survey Division). 2011. Canadian spatial reference system: Online geodetic tools. http://www.geod.nrcan.gc.ca/ tools-outils/index_e.php.

Hill, P.R., Lewis, C.P., Desmarais, S., Kauppaymuthoo, V., and Rais, H. 2001. The Mackenzie Delta: Sedimentary processes and facies of a high-latitude, fine-grained delta. Sedimentology 48(5):1047-1078.

Hollingshead, G.W., and Rundquist, L.A. 1977. Morphology of Mackenzie Delta channels. Proceedings, 3rd National Hydrotechnical Conference, Quebec City, 30-31 May 1977, Canadian Society for Civil Engineering, Ministère des Richesses Naturelles, and Université Laval, Quebec. Vol. 1:309-326.

Inkratas, C., Gharabaghi, B., Beltaos, S., and Krishnappan, B. 2009. 3D modelling of ice-covered flows in the vicinity of a deep hole in the East Channel of the Mackenzie Delta, N.W.T. Canadian Journal of Civil Engineering 36(5):791 -800.

Kamphuis, J.W., Gaskin, P.N., and Hoogendoorn, E. 1990. Erosion tests on four intact Ontario clays. Canadian Geotechnical Journal 27(5):692-696.

Khelifa, A., and Hill, P.S. 2006. Models for effective density and settling velocity of flocs. Journal of Hydraulic Research 44(3):390-401.

Krishnappan, B.G. 2000. Modelling cohesive sediment transport in rivers. In: Stone, M., ed. The role of erosion and sediment 
transport in nutrient and contaminant transfer. IAHS Publication 263. 269-276.

. 2007. Recent advances in basic and applied research in cohesive sediment transport in aquatic systems. Canadian Journal of Civil Engineering 34(6):731 - 743.

Krishnappan, B.G., Chambers, P.A., Benoy, G., and Culp, J. 2009. Sediment source identification: A review and a case study in some Canadian streams. Canadian Journal of Civil Engineering 36(10):1622-1633.

Lapointe, M.F. 1984. Patterns and processes of channel change, Mackenzie Delta, NWT 1983-84 progress report. Ottawa, Ontario: National Hydrology Research Institute, Environment Canada.

1985. Aspects of channel bathymetry and migration patterns in the Mackenzie Delta, NWT. Ottawa, Ontario: National Hydrology Research Institute, Environment Canada.

- 1986a. Deep scour holes on the bed of the Mackenzie Delta channels, NWT. Ottawa, Ontario: National Hydrology Research Institute, Environment Canada.

—. 1986b. Mackenzie Delta channel dynamics: Miscellaneous data. Ottawa, Ontario: National Hydrology Research Institute, Environment Canada.

Lau, Y.L., and Krishnappan, B.G. 1994. Does reentrainment occur during cohesive sediment settling? Journal of Hydraulic Engineering 120(2):236-244.

Mehta, A.J., and Partheniades, E. 1975. An investigation of the deposition properties of flocculated fine sediments. Journal of Hydraulic Research 13(4):361 - 381.

Milburn, D., and Krishnappan, B.G. 2003. Modelling erosion and deposition of cohesive sediments from Hay River in Northwest Territories, Canada. Nordic Hydrology 34(1-2):125 - 138.
Navarro, H.R. 2004. Flume measurements of erosion characteristics of soils at bridge foundations in Georgia. MSc thesis, Georgia Institute of Technology, Atlanta, Georgia. $109 \mathrm{p}$.

NWT (Northwest Territories) Centre for Geomatics. 2011. Mackenzie Valley Air Photo Project 2004. http://www.gnwtgeomatics. nt.ca/RemoteSensing/avhrr/MackenzieValleyPhotos.asp.

Parchure, T.M. 1984. Erosional behavior of deposited cohesive sediments. PhD dissertation, University of Florida, Gainesville, Florida.

Partheniades, E. 1962. A study of erosion and deposition of cohesive soils in salt water. $\mathrm{PhD}$ dissertation, University of California, Berkeley, California.

RD Instruments. 2003. WinRiver User's Guide USGS Version. San Diego, California: RD Instruments. 152 p.

Smerdon, E.T., and Beasley, R.P. 1961. Critical tractive forces in cohesive soils. Agricultural Engineering 42(1):26-29.

T. Blench and Associates Ltd. 1974. Channel geometry and flow data - Mackenzie River-Lower Delta. Prepared for Northern Engineering Services Co. Ltd., Edmonton, Alberta.

Tolhurst, T.J., Black, K.S., and Paterson, D.M. 2009. Muddy sediment erosion: Insights from field studies. Journal of Hydraulic Engineering 135(2):73-87.

WSC (Water Survey of Canada). 2011. Mackenzie River (East Channel) at Inuvik (10LC002); 2010 daily water level (m). http://www.wsc.ec.gc.ca/applications/H2O/report-eng.cfm? yearb $=\&$ yeare $=\&$ station $=10$ LC002\&report=daily\&data $=$ level.

Zhu, Y.H., Lu, J.Y., Liao, H.Z., Wang, J.S., Fan, B.L., and Yao, S.M. 2008. Research on cohesive sediment erosion by flow: An overview. Science in China Series E: Technological Sciences 51(11):2001-2012. 